\title{
Bacterial surface proteins and vaccines Guido Grandi
}

Address: Novartis Vaccines and Diagnostics, Via Fiorentina 1, 53100, Siena, Italy

Email: guido.grandi@novartis.com

Fl000 Biology Reports 2010, 2:36 (doi:10.34I0/B2-36)

The electronic version of this article is the complete one and can be found at: http://fl000.com/reports/biology/content/2/36

\begin{abstract}
Surface-associated proteins play a key role in bacterial physiology and pathogenesis and are the major targets for vaccine development. Recent advances in defining the proteins associated with, and protruding out of, bacterial cells to a high level of accuracy are substantially contributing to accelerating the process of vaccine target identification and development.
\end{abstract}

\section{Introduction and context}

Genomic era and high-throughput technologies represent a turning point in vaccine discovery. The ability to sequence whole genomes and produce hundreds of recombinant proteins rapidly and efficiently has enabled almost entire bacterial proteomes to be scanned by in vivo and in vitro assays to identify the few protective antigens that can be included in vaccine formulations.

The first 'from-genome-to-vaccine' approach was pioneered by Stephen Johnston and colleagues [1], who constructed a plasmid library of the whole Mycoplasma genome and used it with DNA immunization to select the genes that protect mice against Mycoplasma challenge. Although the approach was not further pursued because of the inefficiency of DNA immunization when applied in high-throughput modalities, it represents a hallmark in vaccinology in that it has set the basis for subsequent, more effective strategies. One of these strategies involves the cloning and expression of a large fraction of the bacterial protein repertoire and the screening of each purified recombinant protein in appropriate 'surrogate of protection' assays. This approach was first attempted by Ling Lissolo and coworkers with uncertain results [2] but subsequently proved to be extremely effective by Pizza et al. [3], Maione et al. [4] and Stranger-Jones et al. [5] for an increasing number of pathogens. Vaccines developed following this strategy are currently in advanced clinical studies [6] and close to reaching the market. A second approach involves the shotgun cloning of the whole genome of a given pathogen such that Escherichia coli expression libraries are generated in which clones express protein domains on their surface. The expression libraries are then screened with sera from patients infected by the pathogen of interest and the identified immunogenic proteins are tested for their capacity to elicit protective immunity in animal models [7].

The main limitation of the above technologies is that for them to be effective, several hundreds of proteins have to be tested in extremely time-consuming and laborintensive protection assays, which usually involve animal immunization and challenge.

From an inspection of all antibacterial subunit-based vaccines either on the market or in advanced phases of development, it emerges that their components fall into the categories of secreted toxins or abundantly expressed, surface exposed molecules. Therefore, should effective methods capable of discriminating these molecules from the plethora of bacterial components become available, the development of new vaccines would be greatly accelerated.

\section{Major recent advances}

Today, bioinformatics tools are available to predict surface proteins in bacteria (see [8] and references therein). However, in silico analyses are still incapable of providing solid quantitative information on surface 
protein expression, a severe limitation for vaccine development.

Several experimental procedures have been described for the identification of bacterial surface-associated proteins (reviewed in [9]). They are generally based on (a) chemical-physical methods to fractionate the different cellular compartments, (b) separation of membraneand cell-wall-enriched fractions by gel electrophoresis or chromatography, and (c) mass spectrometry analysis of resolved fractions for protein identification.

In general, these approaches suffer two major limitations. First, fractionation methods aimed at separating the membrane fraction from the other cellular compartments are only partially efficient, with the result that several cytoplasmic proteins usually contaminate the protein mixture undergoing mass spectrometry analysis. Second, most of the methods developed do not provide information on the topological organization of the proteins associated with, or embedded in, the bacterial membrane. This information is particularly relevant for vaccine applications because the protein domains protruding out of the surface are those involved in the interaction with the host immune system.

Other methods for surface protein characterization involve selective biotinylation of whole bacteria with different biotinylating agents and subsequent mass spectrometry analysis of labeled proteins [10-14]. Although quite informative, these methods also suffer from the limitations of being poorly quantitative and selective.

Recently, two strategies have been proposed that at least partially overcome the above mentioned limitations. The first of these strategies has been designed for surfaceexposed protein identification in Gram-positive bacteria. It involves the enzymatic 'shaving' of the bacterial surface with proteolytic enzymes under conditions that preserve the integrity and viability of bacterial cells. After digestion, the released peptides are separated from the 'shaved' bacteria and subjected to mass spectrometry for protein identification. The approach has been successfully applied in surface protein identification of group A $[15,16]$ and group B Streptococcus [17]. In most cases, the presence of the proteins on the bacterial surface has been confirmed by demonstrating that antibodies against the recombinant forms of the identified proteins bind live bacteria, as revealed by fluoresence-activated cell sorting analysis [15]. One key aspect of this approach is that very little contamination with cytoplasmic proteins occurs; therefore, the proteins identified by mass spectrometry are bona fide surface-exposed proteins. In addition, since only the protruding domains are accessible to proteases, the proteolytic peptides generated by the enzymatic treatment belong to the exposed part of the proteins; their characterization thus provides useful information on the topological organization of each identified protein $[15,17]$.

In Gram-negative bacteria, the 'shaving' strategy is difficult to apply because of the relative fragility of the cells, which tend to die during protease treatment. For these bacteria a different approach has been recently developed that exploits their natural propensity to release outer membrane vesicles (OMVs) $[18,19]$. If specific mutations are selected, the amount of released OMVs - usually too small for practical purposes - can substantially increase and reach values of several milligrams (in protein content) per liter of culture $[20,21]$. Because of their small size (50-100 nm in diameter), OMVs can be easily separated from the bacterial cells by centrifugation or ultrafiltration (or both) and then subjected to mass spectrometry analysis for protein identification.

The proteome characterization of OMVs from a Neisseria meningitidis group B isolate and from a pathogenic E. coli strain has been reported recently $[21,22]$. The data show that OMVs almost exclusively contain outer membrane proteins and few periplasmic proteins, exactly as expected considering that they are generated through a 'budding out' of the outer membrane [20]. Interestingly, preliminary data indicate that, in contrast to parent cells, OMVs can be shaved with proteases without impairing their integrity, thus allowing topological studies of surface exposed proteins (Berlanda Scorza, unpublished data).

With these newly developed methods, accurate maps of bacterial surfaces describing protein organization in both topological and quantitative terms will soon be available. The data already generated show that the number of exposed membrane proteins expressed to a sufficiently high level to become the target of protective immune responses is limited to a few tens. As experimentally demonstrated, among them are to be found most, if not all, future vaccines.

\section{Future directions}

Two major aspects remain to be addressed in surface proteome analysis that might have important implications in future vaccine development. First, it is well known that, depending on environmental conditions, bacteria modulate their surface protein organization. So far, surface proteomes have been characterized only under specific and often artificial conditions. Therefore, 
defining the dynamics of protein appearance and disappearance on the bacterial surface will provide important insights in bacterial physiology and pathogenesis. Second, it is expected that certain surfaceexposed proteins interact and constitute functional protein complexes. So far, very little is known about which protein complexes are formed on the bacterial surface and this is a field that awaits future investigation.

\section{Abbreviation}

OMV, outer membrane vesicle.

\section{Competing interests}

The author declares that he has no competing interests.

\section{References}

I. Barry MA, Lay WC, Johnston SA: Protection against mycoplasma infection using expression-library immunization. Nature 1995, 377:632-5.

2. Grandi G: Antibacterial vaccine design using genomics and proteomics. Trends Biotechnol 200I, 19:181-8.

3. Pizza M, Scarlato V, Masignani V, Giuliani MM, Aricò $B$, Comanducci M, Jennings GT, Baldi L, Bartolini E, Capecchi B, Galeotti CL, Luzzi E, Manetti R, Marchetti E, Mora M, Nuti S, Ratti G, Santini L, Savino S, Scarselli M, Storni E, Zuo P, Broeker M, Hundt E, Knapp B, Blair E, Mason T, Tettelin H, Hood DW, Jeffries AC, et al.: Identification of vaccine candidates against serogroup $B$ Meningococcus by whole-genome sequencing. Science 2000 , 287:1816-20.

4. Maione D, Margarit I, Rinaudo CD, Masignani V, Mora M, Scarselli M, Tettelin H, Brettoni C, lacobini ET, Rosini R, D'Agostino N, Miorin L, Buccato S, Mariani M, Galli G, Nogarotto R, Nardi Dei V, Vegni F, Fraser C, Mancuso G, Teti G, Madoff LC, Paoletti LC, Rappuoli R, Kasper DL, Telford JL, Grandi G: Identification of a universal Group B Streptococcus vaccine by multiple genome screen. Science 2005, 309:|48-50.

5. Stranger-Jones YK, Bae T, Schneewind O: Vaccine assembly from surface proteins of Staphylococcus aureus. Proc Natl Acad Sci U S A 2006, I03: 16942-7.

FI000 Factor 6.0 Must Read Evaluated by Vivek Kapur 17 Jan 2007

6. Giuliani MM: A universal vaccine for serogroup B Meningococcus. Proc Natl Acad Sci U S A 2006, 102:10834-9.

7. Etz $\mathrm{H}$ : Identification of in vivo expressed vaccine candidate antigens from Staphylococcus aureus. Proc Natl Acad Sci U S A 2002, 99:6573-8.

FI000 Factor 3.0 Recommended

Evaluated by Vishvanath Nene 25 Jun 2002

8. Giombini E, Orsini M, Carrabino D, Tramontano A: An automatic method for identifying surface proteins in bacteria: SLEP. BMC Bioinformatics 2010, I I:39.

9. Cordwell S5: Technologies for bacterial surface proteomics. Curr Opin Microbiol 2006, 9:320-9.
10. Sabarth N, Lamer S, Zimny-Arndt U, Jungblut PR, Meyer TF, Bumann D: Identification of surface proteins of Helicobacter pylori by selective biotinylation, affinity purification and two-dimensional gel electrophoresis. J Biol Chem 2002, 277:27896-902.

II. Myers-Morales T, Cowan C, Gray ME, Wulff CR, Parker CE, Borchers CH, Straley SC: Surface-focused biotinylation procedure identifies the Yersinia pestis catalase KatY as a membrane-associated but not surface-located protein. Appl Environ Microbiol 2007, 73:5750-9.

12. Ge Y, Rikihisa Y: Surface-exposed proteins of Ehrlichia chaffeensis. Infect Immun 2007, 73:3833-4I.

13. Harding SV, Sarkar-Tyson M, Smither SJ, Atkins TP, Oyston PC, Brown KA, Liu $Y$, Wait R, Titball RW: The identification of surface proteins of Burkholderia pseudomallei. Vaccine 2007, 25:2664-72.

14. Gatlin CL, Pieper R, Huang S-T, Mongodin E, Gebregeorgis E, Parmar PP, Clark, Hamid Alami DJ, Papazisi L, Fleischmann RD, Gill SR, Peterson SN: Proteomic profile of cell envelopeassociated proteins from Staphylococcus aureus. Proteomics 2006, 6:1530-49.

15. Rodríguez-Ortega MJ, Norais N, Bensi G, Liberatori S, Capo S, Mora M, Scarselli M, Doro F, Ferrari G, Garaguso I, Maggi T, Neumann A, Covre A, Telford JL, Grandi G: Characterization and identification of vaccine candidate proteins through analysis of the Group A Streptococcus surface proteome. Nat Biotechnol 2006, 24:191-7.

FI000 Factor 6.4 Must Read Evaluated by Patricia C Weber 04 Apr 2006, Victor Nizet 25 Apr 2006

16. Severin A, Nickbarg E, Wooters J, Quazi SA, Matsuka YV, Murphy E, Moutsatsos IK, Zagursky RJ, Olmsted SB: Proteomic analysis and identification of Streptococcus pyogenes surface-associated proteins. J Bacteriol 2007, I 89: I5 |4-22.

17. Doro F, Liberatori S, Rodríguez-Ortega MJ, Rinaudo CD, Rosini R, Mora M, Scarselli M, Altindis E, D'Aurizio R, Stella M, Margarit I, Maione D, Telford JL, Norais N, Grandi G: Surfome analysis as a fast track to vaccine discovery: identification of a novel protective antigen for Group B Streptococcus hypervirulent strain COHI. Mol Cell Proteomics 2009, 8:I728-37.

18. Kuehn MJ, Kesty NC: Bacterial outer membrane vesicles and the host-pathogen interaction. Genes Dev 2005, 19:2645-55.

19. Mashburn-Warren LM, Whiteley M: Special delivery: vesicle trafficking in prokaryotes. Mol Microbiol 2006, 61:839-46.

20. Bernadac A, Gavioli M, Lazzaroni JC, Raina S, Lloubès R: Escherichia coli tol-pal mutants form outer membrane vesicles. J Bacteriol 1998, I 80:4872-8.

21. Ferrari G, Garaguso I, Adu-Bobie J, Doro F, Taddei AR, Biolchi A, Brunelli B, Giuliani MM, Pizza M, Norais N, Grandi G: Outer membrane vesicles from group B Neisseria meningitidis $\triangle$ gna33 mutant: proteomic and immunological comparison with detergent-derived outer membrane vesicles. Proteomics 2006, 6:1856-66.

22. Berlanda Scorza F, Doro F, Rodríguez-Ortega MJ, Stella M, Liberatori S, Taddei AR, Serino L, Gomes Moriel D, Nesta B, Fontana MR, Spagnuolo A, Pizza M, Norais N, Grandi G: Proteomics characterization of outer membrane vesicles from the extraintestinal pathogenic Escherichia coli $\Delta$ tolR IHE3034 mutant. Mol Cell Proteomics 2008, 7:473-85. 